\title{
Evolution of heat wave occurrence over the Paris basin (France) in the 21st century
}

\author{
Aude Lemonsu* , Anne Lise Beaulant, Samuel Somot, Valéry Masson
}

Centre de Recherches Météorologiques, CNRS / Météo-France, 42 avenue Gaspard Coriolis, 31057 Toulouse cedex, France

\begin{abstract}
We analysed the temporal evolution of heat wave frequency in the Paris region in a changing future climate (1960-1989, 2020-2049, 2070-2099). Firstly, a method for extracting heat waves from observed or simulated time series of daily minimum and maximum temperatures was proposed, based on heat-impact considerations. It was evaluated over the period 1951-2009 using observations from 2 meteorological stations of the Météo-France operational network. The past heat waves that have affected the Paris region were correctly identified in terms of both dates and durations. Eight heat waves were extracted from the data for this period of time (i.e. a mean frequency of about 1 in $7 \mathrm{yr}$ ). The method was then applied to a large sample of climate projections, including 1 regional climate model (RCM) following 3 emission scenarios (A2, A1B, B1) and 9 combinations of RCMs driven by different global circulation models following the A1B emission scenario only (from the European ENSEMBLES project). The historical runs generated 1 to 5 heat waves, depending on the model, with a median value of 3 events (i.e. a frequency of 1 in $10 \mathrm{yr}$ ). All models from the ENSEMBLES database simulated a systematic increase in the frequency of heat wave occurrences with time: 1 heat wave every 2 yr on average over 2020-2049, rising to at least 1, and up to 2, heat waves per year on average over 2070-2099. They also became much longer, with mean durations varying between 6 and 12 d over 2070-2099, and exceptional durations reaching 5 to $9 \mathrm{wk}$. A comparison of the heat waves simulated with the 3 different emission scenarios highlights the major impact of the scenario on the number of heat wave days (and the duration of heat waves) at the end of the 21st century.
\end{abstract}

KEY WORDS: Heat waves $\cdot$ Regional climate models $\cdot$ Reference historical time series $\cdot$ Sources of uncertainties

Resale or republication not permitted without written consent of the publisher

\section{INTRODUCTION}

The impact on climate of the concentration of greenhouse gases (GHG) due to human activities is now well established. It results in global warming, which has already been observed over the past century (Easterling et al. 1997, Houghton et al. 2001) and which is expected to accelerate on a global scale during the 21st century according to climate projections (Meehl \& Tebaldi 2004, Schär et al. 2004, IPCC 2007). This global warming is not only characterized by an increase in the mean temperature, but is also associated with an increase in interannual climate variabil- ity (Giorgi 2006) that promotes the occurrence of certain extreme meteorological events such as heavy precipitation events, droughts, and hot spells. Numerous recent studies and international research projects have looked into the evolution of such extreme events given the fact that they can have dramatic consequences on the ecosystem, and particularly on human beings and their environment (Rosenzweig \& Solecki 2001, Smoyer-Tomic et al. 2003) in terms of water resources, pollution, bioclimatic comfort and health, energy consumption, or infrastructure management.

According to various studies, global circulation models (GCMs) generally simulate future heat waves 
as becoming more frequent, more intense and longer than they have been in the past century, e.g. Huth et al. (2000) with the ECHAM3 model and Meehl \& Tebaldi (2004) with the Parallel Climate Model. More recently, Chauvin \& Denvil (2007) have investigated - on a global scale and in different IPCC (Intergovernmental Panel on Climate Change) scenarios - the evolution of extreme events simulated by the 2 French models, from Centre National de Recherches Météorologiques (CNRM) and Institut Pierre Simon Laplace (IPSL), through a set of severe indexes. They forecast a systematic increase in warm spells at the end of the 21st century. In addition, this trend appears to be faster than that of the mean warming over Europe, probably because of the accompanying evolution of soil moisture conditions (e.g. Fischer et al. 2007, Mueller \& Seneviratne 2012). These results over Europe have been confirmed by Beniston et al. (2007) in the PRUDENCE (Prediction of Regional scenarios and Uncertainties for Defining EuropeaN Climate change risks and Effects) project, using a large set of regional climate model (RCM) simulations. Vautard et al. (2007) have shown that heat waves affecting Europe are frequently preceded by winters characterized by a rainfall deficit in the Mediterranean area.

In France, some studies have already focused on climate change on a country-wide scale, based on observations (Moisselin et al. 2002, Dubuisson \& Moisselin 2006) or climate projections (Gibelin \& Déqué 2003, Déqué 2005, Boé et al. 2006, Martin \& Etchevers 2006, Vautard et al. 2012). Analyses conducted by the climatology division of Météo-France showed a rise in average temperatures over France during the 20th century, slightly greater than that established by the IPCC on a global scale, with significant regional differences in maximum temperature (Moisselin et al. 2002). For the future climate, Planton et al. (2008) highlighted a warming trend in both minimum and maximum temperatures. In addition, several French research projects have recently performed impact studies over the country by addressing various issues, such as changes in meteorological extremes (IMFREX; Déqué 2007), heavy rain events (MEDUP; Beaulant et al. 2011), water resources (REXHYSS; Ducharne et al. 2011), snow cover in mountainous areas (SCAMPEI; Rousselot et al. 2012), and dry spells (CLIMSEC; Najac et al. 2010). In particular, it appears from the IMFREX project that heat waves will increase substantially during the century (Déqué 2007, Planton et al. 2008), but with strong regional variability. These results have recently been confirmed by the work of Lemonsu et al. (2013) on the evolution of the climate of the Paris region. They showed a very significant increase in summertime meteorological indexes (very hot days, tropical nights, and heat wave warnings).

The 2003 heat wave resulted in a mortality excess of 15000 people in France, particularly in the Paris basin (Evin \& d'Aubert 2004, Rousseau 2004). It raised the awareness of the authorities and population about the health impacts of such extreme meteorological events, which are expected to become more and more frequent in the future due to climate change. The study presented here aims to extract and analyze the heat waves (HWs) simulated by an ensemble of climate models over the Paris basin in the present (1950-2000) and future (2001-2100) climate, considering 3 emission scenarios (B1, A1B, A2). The objective is to assess the range of heat waves that may occur through the 21st century in terms of number, duration, and intensity.

\section{ANALYSIS OF HEAT WAVES FROM HISTORICAL TIME SERIES}

\subsection{Reference historical time series}

Appropriate reference historical time series are needed in order to implement and evaluate the method of identification of HWs. In a domain of about $150 \times 150 \mathrm{~km}$ around Paris, 7 meteorological stations from the Météo-France operational network (listed in Table 1) provided historical time series of daily minimum $\left(T_{\mathrm{n}}\right)$ and maximum $\left(T_{\mathrm{x}}\right)$ near-surface air temperature, starting in 1945 for the longest and 1974 for the shortest period and running until 2009. Four of them-Roissy, Evreux, Le Bourget, and Beauvais - could not be used because they were either not homogenized (Moisselin et al. 2002) or not subjected to satisfactory quality control (as mentioned in Table 1). If observations and climate simulations (Section 3.3) are to be compared, the reference stations and the corresponding model grid point must be similar in terms of local climate and surface characteristics. As the climate models used here to extract HW events did not take into account any local effects due to cities, reference stations had to be located in non-urbanized areas. If data from an urbanized station had been used, the effect of the urban heat island on temperature measurements would have disturbed both the identification of regional HWs and the comparison with climate models. As a result, the stations of Orly Airport and Paris Montsouris (in an urban city park of central 
Table 1. Characteristics of the meteorological stations from the Météo-France operational network available in Paris region. Data homogeneity - $\mathrm{H}$ : homogenized; NH: not homogenized; QC: quality control. Data are considered bad quality in the case of a large break in time-series homogeneity. This break can be related, for example, to the change of a sensor, or to the displacement of the station

\begin{tabular}{|lcccc|}
\hline Station & Land use & Time series & $\begin{array}{c}\text { Data } \\
\text { homogeneity }\end{array}$ & $\begin{array}{c}\text { Distance to } \\
\text { Paris (km) }\end{array}$ \\
\hline Beauvais & Rural & $1945-2009$ & H-bad QC & $68(\mathrm{~N})$ \\
Chartres & Rural & $1945-2009$ & H-good QC & $77(\mathrm{SW})$ \\
Evreux & Rural & $1968-2009$ & NH & $85(\mathrm{~W})$ \\
Le Bourget & Airport & $1954-2009$ & H-bad QC & $10(\mathrm{~N})$ \\
Montereau & Rural & $1945-2009$ & H-good QC & $92(\mathrm{SW})$ \\
Orly & Airport & $1954-2009$ & H-good QC & $15(\mathrm{~S})$ \\
Paris Montsouris & City park & $1945-2009$ & H-good QC & $4(\mathrm{~S})$ \\
Roissy & Airport & $1974-2009$ & NH & $20(\mathrm{~N})$ \\
\hline
\end{tabular}

Paris) were excluded. Finally, only the stations of Chartres and Montereau, both of which cover a very long time period and do not present any significant break in temperature records, were kept. The $T_{\mathrm{n}}$ and $T_{\mathrm{x}}$ reference historical time series - calculated as the averages of Chartres and Montereau $T_{\mathrm{n}}$ and $T_{\mathrm{x}}$ time series - were used for the evaluation of HW definition and the comparison with climate model outputs in the rest of the study.

\subsection{Heat wave definition}

According to the literature, there is no universal definition for HWs (Perkins et al. 2012, Perkins \& Alexander 2013). In climate studies, numerous definitions have been proposed (e.g. Huth et al. 2000, Meehl \& Tebaldi 2004, Beniston et al. 2007, Fischer \& Schär 2010, Cueto et al. 2010, Kuglitsch et al. 2010), most of them based on the crossing of a threshold of temperature or on a percentile of temperature associated with a minimum duration. For instance, Kuglitsch et al. (2010) consider periods of 3 or more consecutive hot days and nights. A hot day (night) is defined as a day (night) when the daily $T_{\mathrm{x}}\left(T_{\mathrm{n}}\right)$ exceeds the long-term daily 95th percentile for the June-September season (calculated over 1969-1998 in their study). For Fischer \& Schär (2010), a HW is defined as a spell of at least 6 consecutive days with maximum temperatures exceeding the local 90th percentile of the historical period (1961-1990). In the STARDEX (STAtistical and Regional dynamical Downscaling of EXtremes for European regions) project (Goodess 2003), a HW is defined as a sequence of at least 6 consecutive days with daily maximum tem- peratures of at least $5^{\circ} \mathrm{C}$ above the climatology. The climatology is calculated for a $5 \mathrm{~d}$ window centered on each calendar day in the reference simulation.

In France, following the devastating HW event in the summer of 2003, a national operational warning system called 'Plan National Canicule' (PNC) was set up in 2004 (Maillard 2010), with the objective of helping local authorities in each French administrative county to make decisions in case of HW events. The PNC defines warning levels according to percentile thresholds that are applied to temperature indicators coming from weather forecasts. These minimum and maximum temperature indicators $\left(T I_{\mathrm{n}}\right.$ and $T I_{\mathrm{x}}$ ) are calculated as a moving average of daily minimum $\left(T_{\mathrm{n}}\right)$ and maximum $\left(T_{\mathrm{x}}\right)$ temperatures over 3 consecutive days $(\mathrm{D}, \mathrm{D}+1, \mathrm{D}+2)$ in order to take into consideration the heat-stress cumulative effect in time associated with HWs. The percentile thresholds were first calculated in 14 pilot cities using statistical information on excess mortality data from the French Institute for Public Health Surveillance (InVS, www. invs.sante.fr/en), then extended to all French counties. These percentiles can be converted into temperature thresholds that vary geographically. When thresholds are exceeded for 3 consecutive days or more, the 'Warning and Action' level of PNC is reached. Preventive measures are then implemented by the county authority to face the potential health risks associated with the HW event.

The new HW definition proposed here combines the different approaches based on climatic studies and the PNC, so that it corresponds to the constraints imposed by the use of climatic projections (only certain meteorological variables are available and with limited temporal resolution) while integrating — in a simple way - information on health impact according to the recommendations of Robinson (2001). A HW event is first detected by one or more HW peaks, which are determined when the daily TI values from the reference historical time series exceed the temperature thresholds $\left(T I_{1}\right)$ applied by the PNC for the corresponding county, i.e. $18^{\circ} \mathrm{C}$ for $T I_{n}$ and $34^{\circ} \mathrm{C}$ for $T I_{\mathrm{x}}$ in the present study (Fig. 1). The HW duration is not prescribed, but is determined by all days adjacent to the peaks for which TIvalues are not lower for any extended period (maximum 2 consecutive days) than the first temperature threshold minus $2^{\circ} \mathrm{C}\left(\mathrm{TI}_{2}=\right.$ 


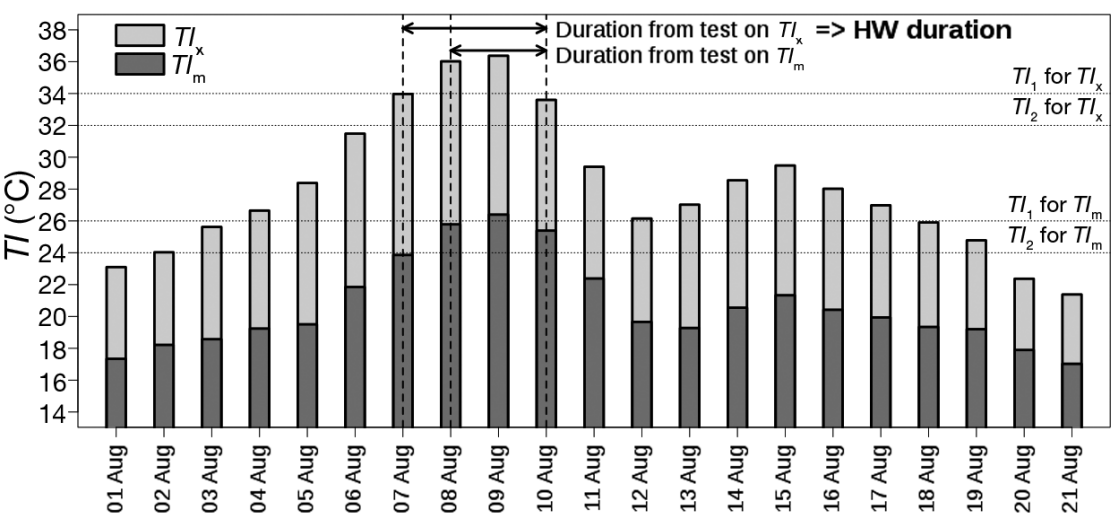

Fig. 1. Example of heat wave (HW) extraction (case of the 1998 heat wave) from observed time series of $T I_{\mathrm{x}}$ and $T I_{\mathrm{m}}$ (see Section 2.2 for definitions) one indicator, and its duration was the maximum duration obtained with one or other of the indicators (as shown in Fig. 1). This approach ensured sufficiently high maximum temperatures, while including days when, although the maximum temperature was slightly below the $T I_{\mathrm{x}}$ threshold, the minimum temperature remained very high. These conditions were relevant for our approach, which aimed to identify HW events that could seriously affect the thermal comfort of the population. High night temperatures during a warm event do not give people the opportunity to recuperate physically.

$T I_{1}-2$; see Fig. 1). In addition, a minimum duration of $3 \mathrm{~d}$ is required for the detected event to be considered a heat wave. It is worth noting that the $T I_{1}$ thresholds defined for Paris by the PNC were not chosen here because they take the urban heat island into account and are consequently higher than those applied in the countryside around the city. The following section gives a detailed description of the thresholds chosen for the purposes of this study.

\subsection{Extraction of heat waves observed in the past}

The proposed definition was evaluated by checking whether it allowed past HWs that have affected the Paris region to be retrieved. The temperature thresholds presented in the previous section were applied to the reference historical time series of $T I_{\mathrm{n}}$ and $T I_{\mathrm{x}}$ (based on the average time series of Chartres and Montereau here) and to $T I_{\mathrm{m}}=\left(T I_{\mathrm{n}}+T I_{\mathrm{x}}\right) / 2$. For $T I_{\mathrm{m}}$, the thresholds were computed as the average of the thresholds of $T I_{\mathrm{x}}$ and $T I_{\mathrm{n}}$, i.e. $T I_{1}=26^{\circ} \mathrm{C}$ and $T I_{2}=$ $24^{\circ} \mathrm{C}$. A battery of tests was conducted to assess the sensitivity and performance of the extraction method according to the conditions for exceeding the threshold. A condition of $T I_{\mathrm{n}}$ and $T I_{\mathrm{x}}$ thresholds being exceeded simultaneously was too restrictive. In some cases, it either shortened the HW duration or it did not extract the event. In addition, applying the condition of exceeding the threshold on $T I_{\mathrm{n}}$ or $T I_{\mathrm{x}}$ was not satisfactory, because numerous days were classified as HW days simply because the minimal temperatures were high by reason of dense cloud cover that limited nocturnal cooling. The best results were obtained by applying the criterion of the threshold being exceeded by the indicators $T I_{\mathrm{x}}$ and $T I_{\mathrm{m}}$ : a heat wave was extracted when the condition was verified for at least
The only information available for the evaluation came from the Météo-France archives documenting the main HW events observed over France since 1950. Based on an expert approach, on a countrywide scale, they indicated only $1 \mathrm{HW}$ event of exceptional intensity (August 2003), $3 \mathrm{HW}$ events of strong intensity $(1976,1983,2006), 7$ HW events of moderate intensity, and $3 \mathrm{HW}$ events of weak intensity (all listed in Table 2). However, this information has to be considered with caution, since the climate of France is geographically diverse and some HW events may not affect the whole country but only certain regions (Fig. 2).

By using the average time series of Chartres and Montereau, the proposed definition identified $8 \mathrm{HW}$ events (see Table 2). The events of June-July 1976 and August 2003, the strongest HWs affecting the Paris area, were particularly well described in terms of date and duration: they lasted, respectively, $14 \mathrm{~d}$ in our observations against $15 \mathrm{~d}$ in the MétéoFrance database for 1976, and 12 d instead $13 \mathrm{~d}$ for 2003. The event of July 2006 was also identified, but was shorter in our observations (12 d against 19), because it affected southern France first, and then the Paris area for about $10 \mathrm{~d}$, which is in accordance with the results obtained here. It also ended $2 \mathrm{~d}$ earlier due to rainy weather that reached the country from the north-west on 26 July, while the HW continued in southeastern France. Finally, the event of July 1983 was not extracted at all in the reference historical time-series, simply because this event affected exclusively Italy and southeastern France (see Fig. 2). Four HWs were retrieved over the Paris region with the present method (1952, 1957, 1990, and 1998) among the 7 events of moderate intensity, and 1 HW (1992), among the 3 events of weak intensity. 
Table 2. Dates and durations of heat wave events (HWs) in the Paris region, extracted from the reference historical time series for the period 1950-2009 and compared with past HWs over France compiled in the Météo-France archives. ${ }^{* *}$ Exceptional intensity; ${ }^{*}$ strong intensity. STARDEX: STAtistical and Regional dynamical Downscaling of Extremes for European regions; PNC: Plan National Canicule

\begin{tabular}{|c|c|c|c|c|c|c|}
\hline \multirow[t]{3}{*}{ Year } & \multirow{2}{*}{\multicolumn{2}{|c|}{$\begin{array}{l}\text { Past HWs over France } \\
\text { Météo-France archives }\end{array}$}} & \multicolumn{4}{|c|}{ Past HWs from historical time series over the Paris region } \\
\hline & & & \multicolumn{2}{|c|}{ STARDEX index } & \multicolumn{2}{|c|}{ Method based on PNC } \\
\hline & Date & Duration $(\mathrm{d})$ & Date & Duration $(\mathrm{d})$ & Date & Duration $(d)$ \\
\hline 1952 & 29 Jun-7 Jul & 9 & - & & 28-30 Jun & 3 \\
\hline 1957 & 29 Jun-7 Jul & 9 & - & & $2-5 \mathrm{Jul}$ & 4 \\
\hline 1975 & 30 Jul-8 Aug & 10 & $30 \mathrm{Jul}-8$ Aug & 10 & - & \\
\hline $1976^{*}$ & $23 \mathrm{Jun}-7 \mathrm{Jul}$ & 15 & 21 Jun-8 Jul & 18 & 23 Jun-6 Jul & 14 \\
\hline $1983^{*}$ & 9-31 Jul & 23 & - & & - & \\
\hline 1989 & 21-24 Jul & 4 & 20-25 Jul & 6 & - & \\
\hline 1990 & 31 Jul-5 Aug & 6 & 30 Jul-5 Aug & 6 & 31 Jul-3 Aug & 4 \\
\hline 1992 & 7-9 Aug & 3 & - & & 5-7 Aug & 3 \\
\hline 1994 & 22 Jul-9 Aug & 19 & 22-27 Jul & 6 & - & \\
\hline 1996 & 19-21 Jul & 3 & - & & - & \\
\hline 1998 & 8-12 Aug & 5 & - & & 7-10 Aug & 4 \\
\hline $2003^{* *}$ & 2-14 Aug & 13 & 2-14 Aug & 8 & 2-13 Aug & 12 \\
\hline 2005 & 18-28 Jun & 11 & 18-25 Jun & 8 & - & \\
\hline $2006^{*}$ & 10-28 Jul & 19 & 15-22 Jul & 8 & 15-26 Jul & 12 \\
\hline
\end{tabular}

The sensitivity of the method to determine HW durations, i.e. the choice of the $\mathrm{TI}_{2}$ threshold and of the number of days during which $T I$ can decrease below $T I_{2}$, was evaluated (not shown here). The impact on past HW retrieval was small: durations varied by only $1-2 \mathrm{~d}$, and the number of extracted events was unchanged. For comparison, the STARDEX index for HW duration (Goodess 2003) was applied to the reference historical time series. Eight of the 14 past HWs were retrieved by this method (Table 2), but 8 additional events, which are not listed in the Météo-France archives, were extracted. In conclusion, the new HW definition seems to be able to identify most of past HWs that have affected the Paris area. It is important to emphasize that, unlike the STARDEX index, this definition did not retrieve extra HWs, which confirms the relevance of the chosen thresholds and of the HW-day aggregation method. Finally, it should be noted that the definition of heat wave proposed here, which was first implemented for extracting heat waves over the Paris region, has also been tested over various other locations in France. The results presented in the Appendix show the robustness of the method.
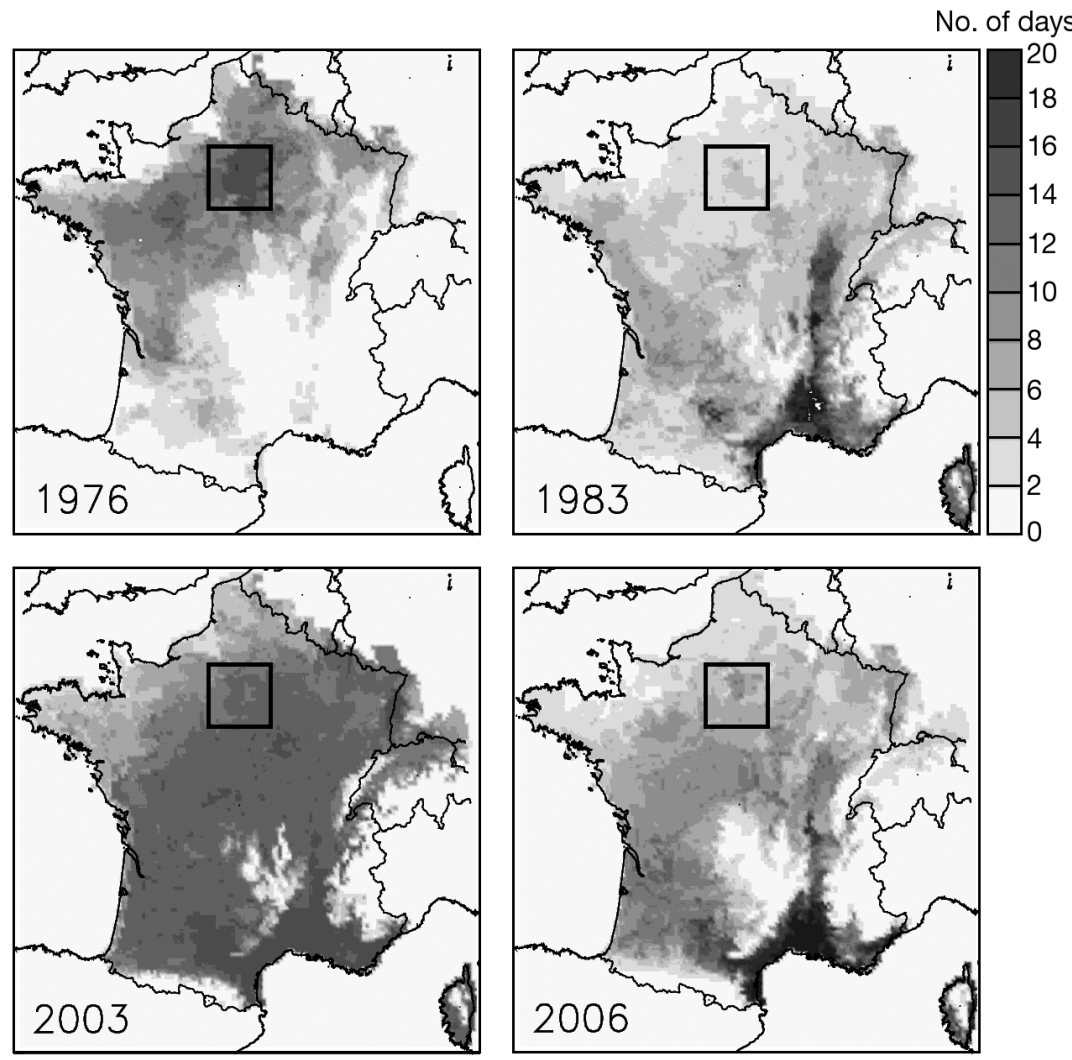

Fig. 2. Number of days with $T I_{\mathrm{x}} \geq 34^{\circ} \mathrm{C}$ and $T I_{n} \geq 18^{\circ} \mathrm{C}$ computed for each period of heat wave identified in the Météo-France archives, based on SAFRAN reanalyses (produced with the SAFRAN system of Durand et al. [1993, 1999] by combining European Centre for Medium-Range Weather Forecasts global reanalysis archives and all available surface observations from the Météo-France climatological database). Black square in each panel: study area 


\section{EXTRACTION OF HW EVENTS FROM CLIMATE PROJECTIONS}

\subsection{Climate models}

Two main databases of climate simulations were used, and provided daily minimum and maximum temperature time series from 1950 to 2099. The emission scenarios were applied from 2001.

The first set of climate projections was conducted with the variable-resolution ARPEGE-Climate-v4 model (Gibelin \& Déqué 2003). This version of the model covers France at a $50 \mathrm{~km}$ spatial resolution using a stretched grid approach. These projections were performed using A2, A1B, and B1 emission scenarios (IPCC 2007). We recall here that the A2 scenario is the most pessimistic scenario in terms of temperature since it gives a global average increase of $2.0-5.4^{\circ} \mathrm{C}$ for the end of the $21 \mathrm{st}$ century. The B1 scenario is the most optimistic, with an increase of 1.1$2.9^{\circ} \mathrm{C}$. For the A1B scenario, the range of temperature increase is between the other scenarios (IPCC 2007).

The second set of projections came from the RT3 database of the European ENSEMBLES project (Christensen et al. 2008, van der Linden \& Mitchell 2009), which brings together climate simulations produced by a wide panel of European RCMs with a spatial resolution of $25 \mathrm{~km}$. Projections are driven by 3 GCMs from Météo-France (CNRM-CM3), the Max Planck Institute (ECHAM), and the Hadley Centre (HadCM) following the A1B emission scenario only. Nine experiments with the database (listed in Table 3; more details at http://ensemblesrt3.dmi.dk) were selected here: they covered the time period of interest, i.e. 1950-2099, and provided the necessary daily minimum and maximum temperatures.
In conclusion, the first set of simulations-1 model following 3 emission scenarios-provided information on the uncertainty due to emissions, whereas the second set-several models using 1 emission scenario-gave access to the uncertainty related to the choice of model. Déqué et al. (2007) demonstrated that model uncertainty can compare with scenario uncertainty, depending on the variables and seasons.

\subsection{Simulated time series}

By combining data from Météo-France and ENSEMBLES databases, 12 time series of daily minimum and maximum temperatures covering 19502099 were obtained (using the model grid points closest to Paris for all climate projections). Note that the 3 ARPEGE simulations had the same historical run whatever the emission scenario. Fig. 3 compares model outputs and Chartres-Montereau observations as a quantile-quantile (q-q) plot over the period 1960-1989 (only for May-October, which is the period of interest for HWs). It shows that RCMs driven by CNRM-CM3 and HadCM tend to strongly overestimate temperatures (both for $T_{\mathrm{n}}$ and $T_{\mathrm{x}}$ ). This point is in agreement with the conclusion drawn concerning GCM drivers in the ENSEMBLES report (van der Linden \& Mitchell 2009). ARPEGE, and also REGCM, RACMO, and REMO (the last 3 driven by ECHAM), are in rather good agreement with observations. An overestimation of the extremes is, however, observed in the very highest tail of distributions. These biases may be due to a misrepresentation of physical processes by climate models under such conditions (Déqué et al. 2007, Christensen et al. 2008, Casati et al. 2013). Finally, RCA (driven by

Table 3. List of climate simulations used for the extraction of heat wave events (HWs) over the Paris region. GCM: global climate model; RCM: regional climate model

\begin{tabular}{|lccccc|}
\hline Institute & Scenario & GCM & RCM & $\begin{array}{c}\text { Resolution } \\
(\mathrm{km})\end{array}$ & References \\
& & & & & \\
\hline Météo-France & B1, A1B, A2 & CNRM-CM3 & ARPEGE & 50 & Gibelin \& Déqué (2003) \\
Météo-France & A1B & CNRM-CM3 & ALADIN5.1 & 25 & Colin et al. (2010) \\
Danish Meteorological Institute & A1B & CNRM-CM3 & HIRHAM5 & 25 & Christensen et al. (1996) \\
Danish Meteorological Institute & A1B & ECHAM5 & HIRHAM5 & 25 & Christensen et al. (1996) \\
International Center for Theoretical Physics & A1B & ECHAM5 & REGCM3 & 25 & Giorgi \& Mearns (1999) \\
Royal Netherlands Meteorological Institute & A1B & ECHAM5 & RACMO2 & 25 & Lenderink et al. (2003) \\
Max Planck Institute & A1B & ECHAM5 & REMO & 25 & Jacob (2001), Jacob et al. (2001) \\
Swedish Meteorological Hydrological Institute & A1B & ECHAM5 & RCA & 25 & Kjellström et al. (2005) \\
Swiss Federal Institute of Technology Zurich & A1B & HadCM3 & CLM & 25 & Böhm et al. (2006) \\
UK Meteorological Office-Hadley Centre & A1B & HadCM3 & HadRM3Q0 & 25 & Collins et al. (2006) \\
\hline
\end{tabular}



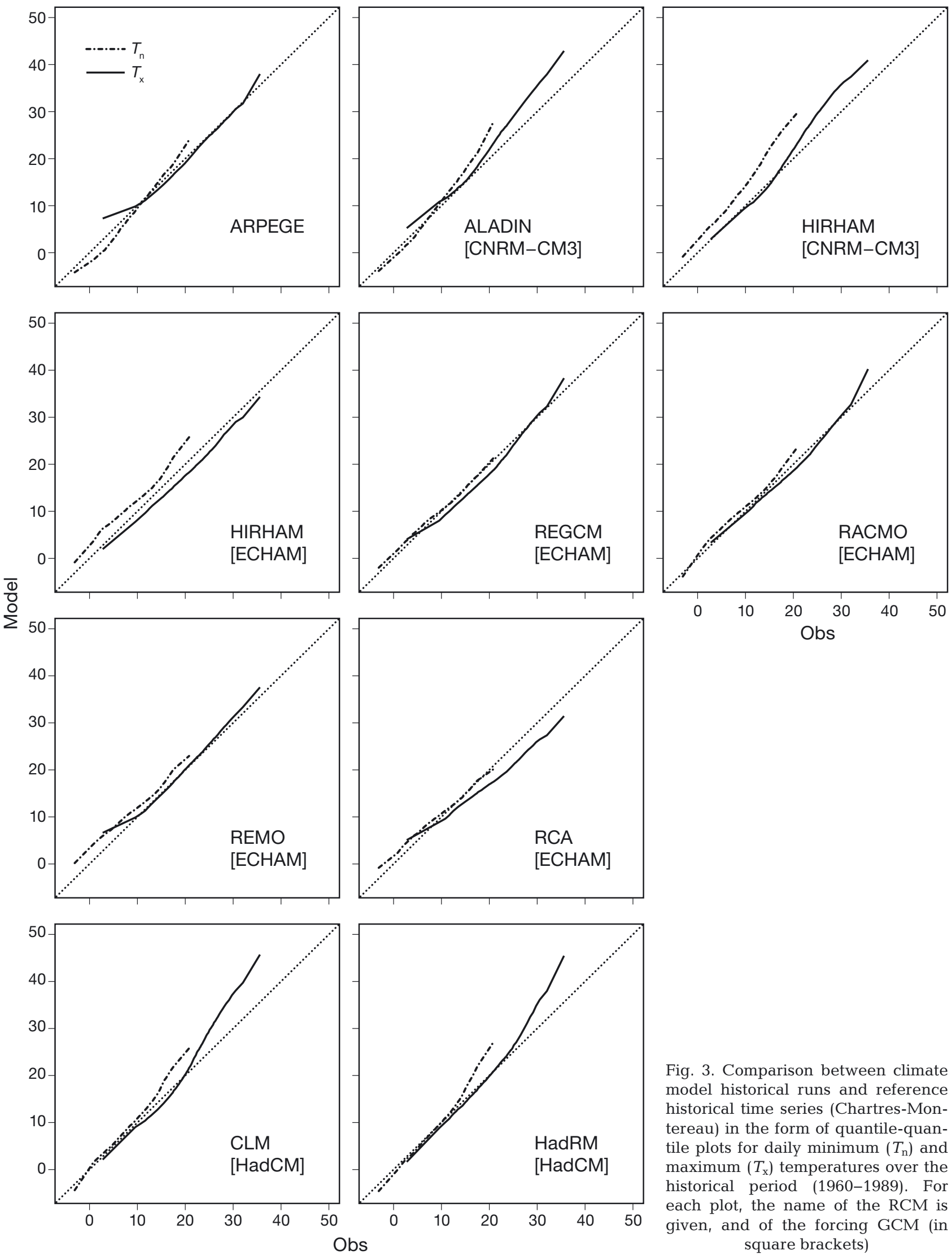

Fig. 3. Comparison between climate model historical runs and reference historical time series (Chartres-Montereau) in the form of quantile-quantile plots for daily minimum $\left(T_{\mathrm{n}}\right)$ and maximum $\left(T_{\mathrm{x}}\right)$ temperatures over the historical period (1960-1989). For each plot, the name of the RCM is given, and of the forcing GCM (in square brackets) 
ECHAM) tends to underestimate $T_{\mathrm{x}}$ as does HIRHAM (also driven by ECHAM), which, in addition, overestimates $T_{n}$.

In order to apply the method of HW extraction based on temperature thresholds to the simulated time series, all models were first adjusted by the $q-q$ matching correction method proposed by Déqué (2007). This consists of computing a correction function by considering the q-q plot of model outputs versus observations over the same historical period, and applying it to the simulated variables. Model biases were assumed to be independent of GHG emissions (Wilby et al. 1998) and, consequently, stationary with time. The same correction functions were thus applied to adjust model outputs in a future climate. Here, seasonal correction functions (May-October) were determined for $T_{\mathrm{n}}$ and $T_{\mathrm{x}}$ by comparing the reference historical time series with all modeled time series over the 1960-1989 period (Fig. 3).

Applying such a correction method was motivated here by the requirement to extract the HWs by using absolute temperature thresholds with health impacts (based on statistical analysis of excess mortality from the InVS). This type of approach has been applied previously for similar issues, e.g. by Casati et al. (2013) for several Canadian communities. Teutschbein \& Seibert (2012) and Maraun (2012) show the relevance of the q-q matching correction method for improving climate projections on average. Besides, as mentioned by Casati et al. (2013), this correction technique is able to capture and partially correct RCM misrepresentations of some physical processes in future climate projections if these defects already appear in the present climate for which the correction function is established. However, the stationary hypothesis on which it is based is not always valid (Driouech et al. 2010), which makes it impossible to correct any bias linked with the new physical processes observed in a changing climate. Maraun (2012) investigated this issue by using ENSEMBLES RCM projections over Europe. He showed that significant changes in the biases are found in the Alps for $T_{\mathrm{n}}$ and in central Europe for $T_{\mathrm{x}}$. In conclusion, in view of the literature results, it seemed appropriate to apply the q-q matching correction method (Déqué 2007) in the present study.

Past and future HWs were then extracted from the simulated time series of temperature indicators which were calculated from the corrected $T_{\mathrm{n}}$ and $T_{\mathrm{x}}$ time series. First, the 1960-1989 historical period was used in order to evaluate the ability of climate models to simulate HWs over the Paris region. Then, 2 future time periods (2020-2049 and 2070-2099) were analyzed to study the evolution of HWs.

\subsection{Evaluation of past modeled heat waves}

The evaluation of climate models consisted in verifying that modeled HWs were comparable to past observed HWs from a statistical point of view. Only 1 HW, of 14 d, was extracted from the 1960-1989 reference historical time series (see Table 4). In comparison, the 10 climate projections simulated between 1 and $5 \mathrm{HWs}$, depending on the experiments (Table 4), with a median value of $3 \mathrm{HWs}$. The duration of HWs varied from 3 to $11 \mathrm{~d}$, with a median value of $5 \mathrm{~d}$, and the number of cumulative HW days varied from 4 to $33 \mathrm{~d}$, with a median value of $19 \mathrm{~d}$. Obviously, the highly unpredictable nature and the rarity of such extreme events, as well as the short period of analysis (only 30 yr), made statistical comparison difficult.

For a more objective assessment of the ability of RCMs to simulate past HWs, 100 random draws of 30 yr with replacement were carried out from the observed and simulated time series over 1951-2000. This bootstrapping technique was performed for blocks of 6 mo (May-October) of a given year for the $T_{\mathrm{n}}$ and $T_{\mathrm{x}}$ time series, which had been previously detrended from present climate, i.e. by removing the mean trends computed from the yearly time series of $T_{\mathrm{n}}$ and $T_{\mathrm{x}}$ averaged year-by-year for May-October of 1951-2000. Once the new $T_{\mathrm{x}}$ and $T_{\mathrm{n}}$ time series had been randomly built, the trend in the present climate was applied again (for each RCM as well as for observations). New $T I_{\mathrm{x}}$ and $T I_{\mathrm{m}}$ time series were then computed and used to extract heat waves. From the analysis of HWs for the 100 draws, we deduced the mean values and standard deviations of the number of events, of their durations, and of their daily mean and maximum temperature indicators $\left(T I_{\mathrm{m}}\right.$ and $\left.T I_{\mathrm{x}}\right)$ that had been averaged for each HW. The results show that HWs simulated by most climate models were within the range of variation of those observed, in terms of both the occurrence of events and their characteristics (Fig. 4). It is noteworthy, however, that both RCMs driven by HadCM, as well as HIRHAM driven by ECHAM, tended to simulate too many HWs with mean values beyond the observed data (computed as mean value + standard deviation). It is also noteworthy that the event observed during the historical period was exceptional in both its duration (14 d, whereas the mean duration derived from the statistical analysis was around $6.6 \mathrm{~d})$ and its temperatures $\left(32.8^{\circ} \mathrm{C}\right.$ vs. $29.9^{\circ} \mathrm{C}$ for $T I_{\mathrm{x}}$ and $25.3^{\circ} \mathrm{C}$ vs. $23.2^{\circ} \mathrm{C}$ for $T I_{\mathrm{m}}$ ). 
Table 4. Number of heat wave events (HWs), number of cumulative HW days (HWd), and HW duration range (in days) for HWs identified in climate simulations over the historical period (1960-1989) and 2 future periods (2020-2049 and 2070-2099) and observations. B1, A1B, A2: climate change scenarios

\begin{tabular}{|c|c|c|c|c|c|c|c|c|c|}
\hline & \multicolumn{3}{|c|}{ 1960-1989 } & \multicolumn{3}{|c|}{$2020-2049$} & \multicolumn{3}{|c|}{ 2070-2099 } \\
\hline & HWs & HWd & Duration & HWs & HWd & Duration & HWs & HWd & Duration \\
\hline \multicolumn{10}{|l|}{ Model simulations } \\
\hline ARPEGE (B1) & 1 & 6 & 6 & 18 & 126 & $3-19$ & 40 & 374 & $3-30$ \\
\hline ARPEGE (A1B) & 1 & 6 & 6 & 14 & 124 & $3-24$ & 60 & 692 & $3-38$ \\
\hline ARPEGE (A2) & 1 & 6 & 6 & 21 & 129 & $3-24$ & 60 & 992 & $3-70$ \\
\hline ALADIN-CNRM-CM3 & 5 & 21 & $3-5$ & 21 & 180 & $3-20$ & 48 & 561 & $3-31$ \\
\hline HIRHAM-CNRM-CM3 & 3 & 16 & $3-8$ & 5 & 29 & $3-12$ & 33 & 384 & $3-53$ \\
\hline HIRHAM-ECHAM & 3 & 19 & $5-9$ & 7 & 37 & $3-9$ & 6 & 39 & $3-11$ \\
\hline REGCM-ECHAM & 2 & 8 & $4-4$ & 8 & 45 & $3-10$ & 39 & 230 & $3-13$ \\
\hline RACMO-ECHAM & 4 & 25 & $4-8$ & 14 & 80 & $3-15$ & 49 & 384 & $3-28$ \\
\hline REMO-ECHAM & 3 & 20 & $3-10$ & 6 & 35 & $3-8$ & 31 & 206 & $3-22$ \\
\hline RCA-ECHAM & 1 & 4 & 4 & 6 & 32 & $3-10$ & 32 & 229 & $3-15$ \\
\hline CLM-HadCM & 4 & 31 & $4-11$ & 21 & 178 & $3-16$ & 42 & 464 & $3-62$ \\
\hline HadRM-HadCM & 4 & 24 & $3-11$ & 21 & 163 & $3-17$ & 48 & 511 & $3-65$ \\
\hline \multicolumn{10}{|l|}{ Observations } \\
\hline Chartres/Montereau & 1 & 14 & 14 & & & & & & \\
\hline Urban & 6 & 49 & $3-16$ & & & & & & \\
\hline
\end{tabular}
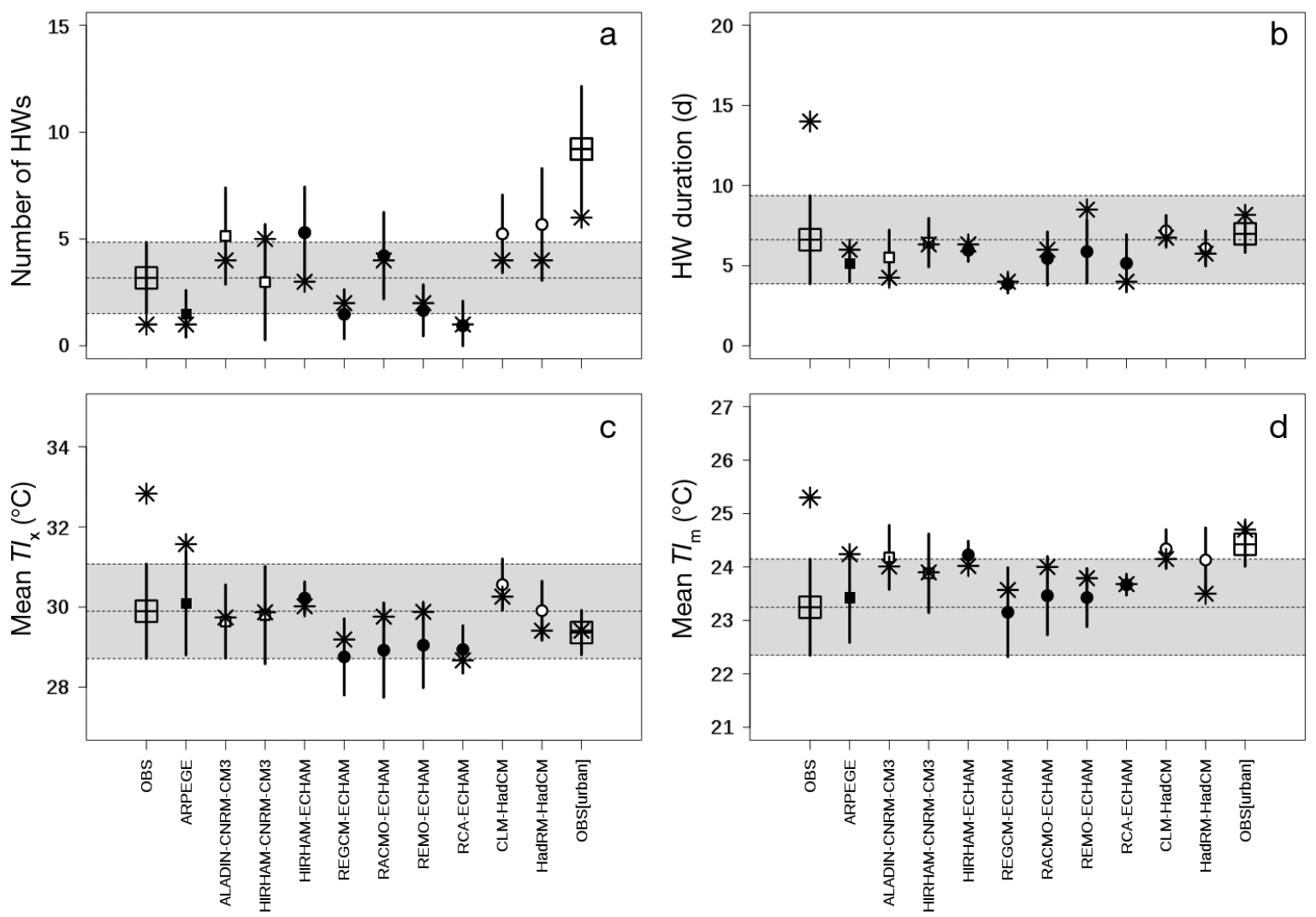

Fig. 4. Comparison of observed and simulated heat wave events (HWs), based on the analysis of 100 random draws of 30 yr, with replacement performed from the 1951-2000 time series. The symbols and vertical bars are, respectively, the mean values and standard deviations computed for (a) the number of extracted HWs and (b) their durations, and also for their mean (c) $T I_{\mathrm{x}}$ and (d) $T I_{\mathrm{m}}$ (see Section 2.2 for definition). Distinct symbols are used to distinguish observations and groups of RCMs driven by different GCMs. Stars: characteristics of HWs extracted over the historical period (1960-1989) (cf. Table 4). Shaded area: standard deviation for observed HWs in order to visualize how simulated HWs compare with observations 


\section{OCCURRENCE OF FUTURE HEAT WAVES}

Future HWs were successively analyzed for the 2 databases of climate projections. For each of them, the number of HWs, the number of cumulative HW days, and the HW durations were computed separately for each climate projection over the different time periods (Table 4 ). These results are presented in the form of boxplots in Figs. 5 \& 6. It should be noted that the analysis was performed by using only one $30 \mathrm{yr}$ sample per period, which may not be fully representative of the models' behavior. The samples were, however, too short to allow the use of a bootstrap technique to derive larger samples for comparison.

\subsection{Uncertainty related to model choice for the A1B emission scenario}

According to Fig. 5a, all models from the ENSEMBLES database simulate a systematic increase in the frequency of occurrence of HWs with time, but there is significant variability among them, both with regard to the number of events and to the trends over the 21st century. First, HIRHAM (driven by ECHAM) differs from the others by simulating very few events: from 3 HWs over the historical period to 7 in 20202049 and only 6 in 2070-2099 (Table 4). ALADIN (driven by CNRM-CM3), and CLM and HadRM (both driven by HadCM) display a sharp increase between 1960-1989 and 2020-2049, during which > 21 events are counted (Table 4 ). The frequency of occurrence of HWs is slightly more than doubled between 2020-2049 and 2070-2099. For HIRHAM (driven by CNRM-CM3) and other models driven by ECHAM, the increase is more significant in the second part of the century than in the first part, except for RACMO (driven by ECHAM), which indicates a constant trend. Finally, without considering the particular case of HIRHAM (driven by ECHAM), the climate projections give between 31 and $49 \mathrm{HWs}$ over 2070-2099 (Table 4), i.e. between 1 and $2 \mathrm{HWs} \mathrm{yr}^{-1}$ (Fig. 5). For comparison, the Paris region was affected by 8 HWs between 1950 and 2009, which corresponds to a frequency of 1 in $7 \mathrm{yr}$.

Besides increasing in number, the HWs also become longer. The analysis of the events extracted separately for each model indicated that their average durations reached 6-12 d over the period 20702099 compared with 5-8 d over 1960-1989 and 2020-2049 (not shown). In addition, a majority of climate projections (both RCMs driven by CNRM-CM3, both RCMs driven by HadCM, and RACMO driven by ECHAM) simulated a significant number of events (>15\%) of 2 wk or more (Fig. 5 c). Several HWs with exceptional durations of 5-9 wk were also retrieved at the end of the 21 st century.

The variability between models - for 30 yr periods - resulted in significant standard deviations of about 7 HWs and 67 cumulative HW days over 2020-2049 (for mean values of about $12 \mathrm{HWs}$ and $86 \mathrm{HW}$ days), and standard deviations of $13 \mathrm{HWs}$ and $170 \mathrm{HW}$ days over 2070-2099 (for mean values of $36 \mathrm{HWs}$ and $334 \mathrm{HW}$ days). Although the set of climate projections studied here is not large enough to objectively make conclusions on the issue of model uncertainty, it seems that both the choice of GCM and the choice of RCM contribute to the uncertainty in HW changes. Fig. 5 (2070-2099 period) shows that HWs simulated by RCMs driven by ECHAM always respond less to climate change than those in RCMs driven by CNRM-CM3 or by HadCM, but HIRHAM simulations also are always on the low-responding side whatever the GCM used. These results are in line with those obtained by Déqué et al. (2007) and confirmed by Déqué et al. (2012) for the summer season.

\subsection{Uncertainty related to emission scenarios for one climate model}

According to ARPEGE climate projections, 18, 14, and 21 HWs were simulated in 2020-2049 following B1, A1B, and A2 scenarios, respectively, and 40,60, and 57 HWs in 2070-2099, while only $1 \mathrm{HW}$ was simulated over the historical period (Table 4). The cumulative number of HW days increased from $6 \mathrm{~d}$ in 19601989 to 126,124 , and 129 d in 2020-2049 following B1, A1B, and A2 scenarios, respectively, and then 374, 692, and 992 d in 2070-2099 (Table 4). This shows, first, that ARPEGE (like the models of the ENSEMBLES project) simulates a very marked increase in the frequency of occurrence of HWs and in the number of HW days regardless of the emission scenario.

The differences between emission scenarios can be put in perspective with the inter-model variability assessed from the climatic projections of the ENSEMBLES database. For 2020-2049, the difference between scenarios is not significant, either in number of HWs or in number of cumulative HW days simulated with the A2, A1B, and B1 emission scenarios, since the standard deviations obtained with the ENSEMBLES models are about 7 for the number of HWs and 67 for the cumulative HW days. For 2070-2099, the number of HWs simulated by ARPEGE with A1B and A2 remains the same, with 57-60 events, but, in con- 

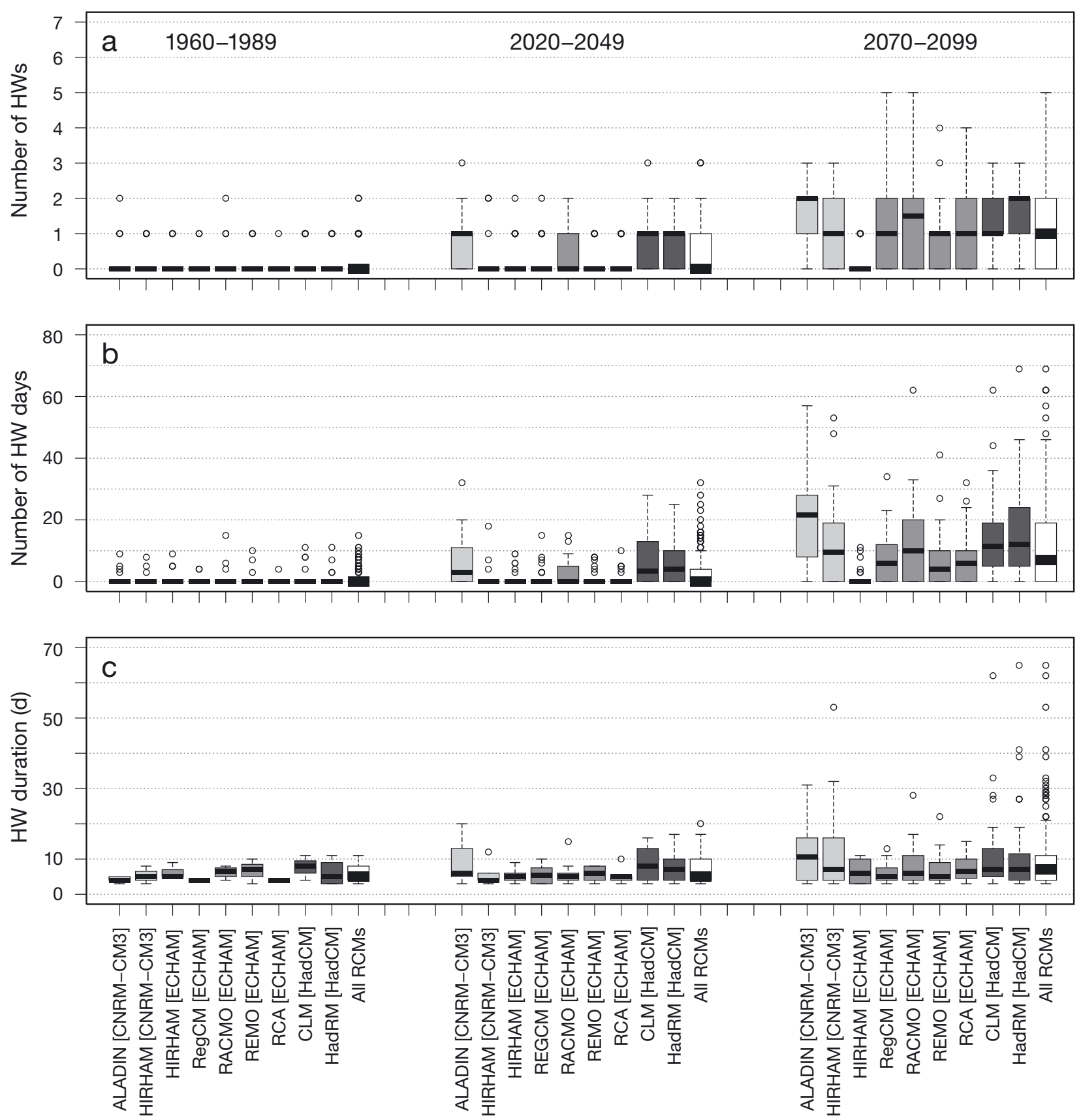

Fig. 5. Boxplots of (a) number of heat wave (HW) events, (b) number of cumulated HW days, and (c) HW duration computed on a year-by-year basis for all RCMs of the ENSEMBLES database. Each gray box corresponds to 1 model (light, medium, and dark gray is for RCMs driven by CNRM-CM3, ECHAM, and HadCM, respectively), whereas the white box integrates all models. The boxplots represent the statistical characteristics of the data samplings. The bottom and top of the box are the first (Q1) and third (Q3) quartiles, and the height of the box is the interquartile range (IQR = Q3 - Q1). The black line inside the box is the median. The downward and upward whiskers extend, respectively, to Q1 - $1.5 \times$ IQR and Q3 + $1.5 \times$ IQR. Data which are not included in this interval are represented by open circles

trast, B1 leads to far fewer HWs (17-30 events less, i.e. $>30 \%$ less), which is significant compared to a standard deviation of 13 for the number of HWs simulated by the ENSEMBLES models. Finally, with the A2 emission scenario, ARPEGE simulates 1.4 and 2.6 times more cumulative HW days than with A1B (692 HW days) and B1 (374 HW days) scenarios, respectively, for 2070-2099. These differences are considerably larger than the standard deviation of $170 \mathrm{HW}$ days obtained for the ENSEMBLES models. 

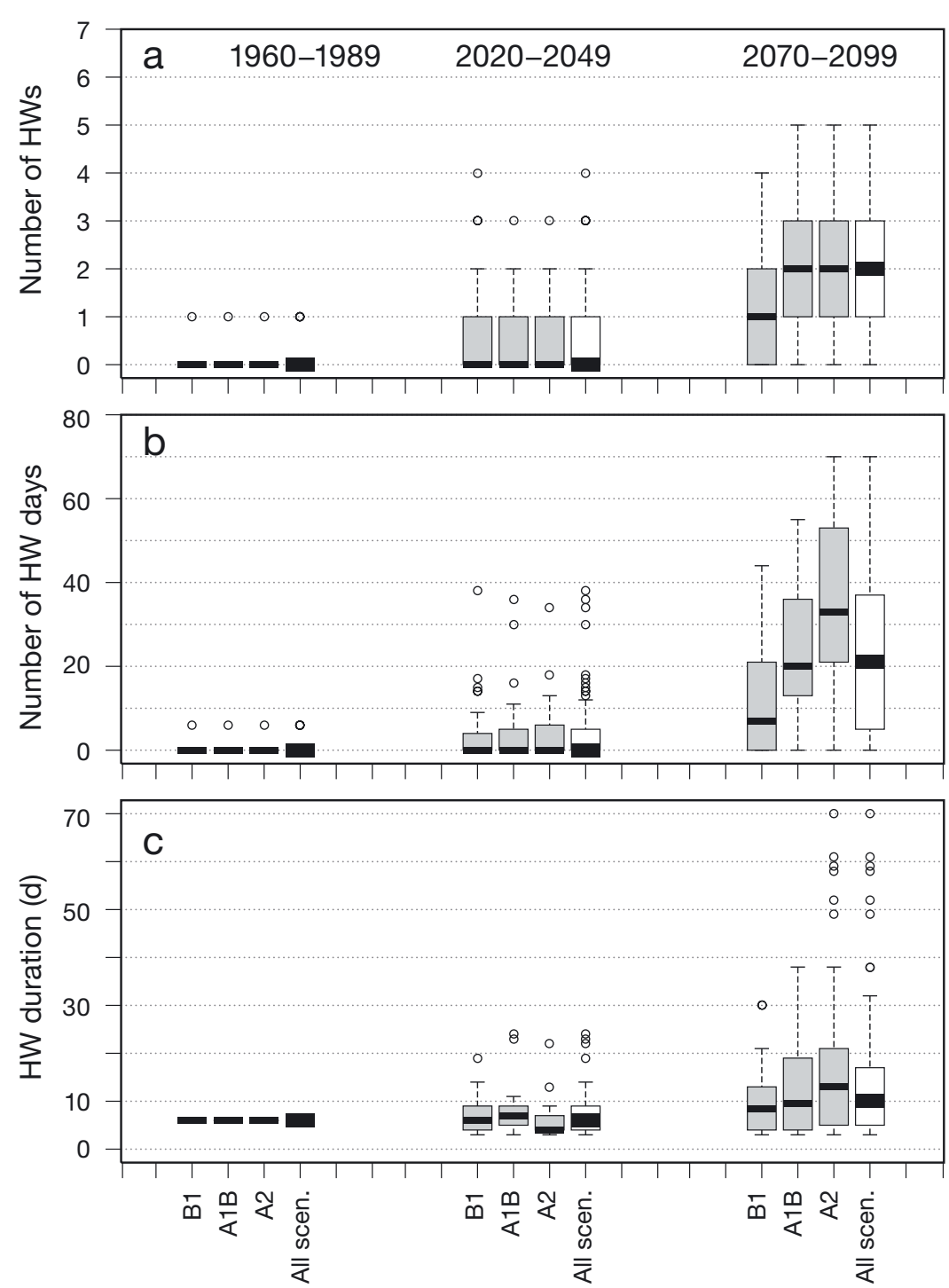

Fig. 6. Boxplots for (a) number of heat wave (HW) events, (b) number of cumulated HW days, and (c) HW duration computed on a year-by-year basis for the 3 emission scenarios (B1, A1B, A2) simulated with ARPEGE. Each gray box corresponds to 1 emission scenario, whereas the white box integrates all scenarios

In conclusion, analysis on a year-by-year basis indicates that the $\mathrm{A} 1 \mathrm{~B}$ and $\mathrm{A} 2$ emission scenarios agree on mean and median values of $2 \mathrm{HWs}$ per year in 2070-2099 against $1 \mathrm{HW}$ for B1 (Fig. 6). However, the events are longer with A2 ( $>17 \mathrm{~d}$ on average) than with A1B (>11 d), and B1 (9 d). The emission scenario has a major impact on the number of HW days (and the duration of HWs) at the end of the 21st century. Globally, these trends are consistent with the fact that B1 and A2 are the scenarios that induce the lowest and highest increases, respectively, in globalscale temperatures (with intermediate trends for A1B).

\subsection{Characteristics of future heat waves}

Some statistics on temperatures of HWs were calculated and are presented in this section in order to analyze the evolution with time of HW characteristics. Each HW is associated with a simulated time series of daily minimum temperature $\left(T_{\mathrm{n}}\right)$ and of daily maximum temperature $\left(T_{\mathrm{x}}\right)$, from which the mean and maximum values of $T_{\mathrm{n}}$ and $T_{\mathrm{x}}$ were computed. This work was done separately for all HWs extracted in the Mété-France and ENSEMBLES databases, and for the different time periods (1960-1989, 20202049, and 2070-2099). It is important to remember that all climate projections had been previously adjusted by the qq matching correction method (Déqué 2007) described in Section 3.2. Table 5 compares $T_{\mathrm{n}}$ and $T_{\mathrm{x}}$ mean and maximum values of all HW events for each time period and each database, by specifying the median of each sample, as well as the upper quartile to focus on the most extreme events (the method of HW extraction, which is based on when thresholds are exceeded, implies that a large number of events are characterized by temperatures that are slightly above the prescribed thresholds).

For HWs simulated by the ENSEMBLES models, both median values and upper quartiles display a systematic increase in mean $T_{\mathrm{n}}$ and $T_{\mathrm{x}}$ between 1960-1989 and 2020-2049 and between 2020-2049 and 2070-2099. The increase is less pronounced for $T_{\mathrm{x}}$ than for $T_{\mathrm{n}}\left(+0.4^{\circ} \mathrm{C}\right.$ vs. $+0.6^{\circ} \mathrm{C}$ for the median and $+0.6^{\circ} \mathrm{C}$ vs. $+1.1^{\circ} \mathrm{C}$ for the upper quartile between 2020-2049 and 2070-2099), which corresponds to the general trend of temperature evolution in summer (not shown here). Thus, at the end of the 21st century, the median value for the mean $T_{\mathrm{n}}$ reaches $19.1^{\circ} \mathrm{C}$, which is largely above the threshold of HW detection for $T I_{\mathrm{n}}\left(T I_{1}=18^{\circ} \mathrm{C}\right)$. In comparison, the median value for the mean $T_{\mathrm{x}}$ reaches only $33.2^{\circ} \mathrm{C}$. The same trends are globally highlighted for the maximum $T_{\mathrm{n}}$ and $T_{\mathrm{x}}$, but are even stronger.

For ARPEGE, the comparison between 1960-1989 and 2020-2049 is not statistically significant because 
Table 5. Median value and upper quartile (parentheses) of the mean and maximum values of the daily minimum ( $\left.T_{\mathrm{n}}\right)$ and maximum temperatures $\left(T_{\mathrm{x}}\right)$ of each heat wave computed for 1960-1989, 2020-2049, and 2070-2099. Statistical results are presented only for the samples containing at least 15 events

\begin{tabular}{|c|c|c|c|c|c|c|}
\hline & 1960-1989 & $\begin{array}{c}T_{\mathrm{n}} \\
2020-2049\end{array}$ & 2070-2099 & 1960-1989 & $\begin{array}{l}T_{\mathrm{x}} \\
2020-2049\end{array}$ & 2070-2099 \\
\hline \multicolumn{7}{|l|}{ Mean } \\
\hline ENSEMBLES (A1B) & $18.1(18.4)$ & $18.5(19.2)$ & 19.1 (20.3) & 33.1 (33.6) & $32.8(33.6)$ & $33.2(34.2)$ \\
\hline ARPEGE (B1) & - & $16.2(17.4)$ & $16.6(17.6)$ & - & 33.4 (34.3) & 33.7 (34.6) \\
\hline ARPEGE (A1B) & - & $16.7(17.2)$ & 17.7 (18.6) & - & $33.6(34.2)$ & $34.3(35.0)$ \\
\hline ARPEGE (A2) & - & $16.5(17.4)$ & $18.2(19.1)$ & - & $33.6(34.1)$ & $33.9(34.8)$ \\
\hline \multicolumn{7}{|l|}{$\operatorname{Max}$} \\
\hline ENSEMBLES (A1B) & $20.2(21.2)$ & 21.1 (23.9) & $22.8(27.4)$ & 35.3 (36.3) & $35.9(37.7)$ & $36.6(41.3)$ \\
\hline ARPEGE (B1) & - & 18.3 (21.9) & $20.0(21.7)$ & - & $36.6(37.6)$ & $37.8(38.6)$ \\
\hline ARPEGE (A1B) & - & $19.5(21.1)$ & $21.9(25.0)$ & - & $36.6(38.1)$ & $38.3(40.3)$ \\
\hline ARPEGE (A2) & - & $20.0(20.5)$ & $22.6(25.8)$ & - & 36.5 (36.8) & $38.1(40.4)$ \\
\hline
\end{tabular}

only 1 event is identified during the historical period. In the same way as for the ENSEMBLES projections, the mean and maximum values of $T_{\mathrm{n}}$ and $T_{\mathrm{x}}$ increase between 2020-2049 and 2070-2099. Again, $T_{\mathrm{n}}$ increases more than $T_{\mathrm{x}}$. For $T_{\mathrm{n}}$ only, the trends vary differently depending on the emission scenario: +0.4 $(+1.7)^{\circ} \mathrm{C}$ for the mean and maximum values of $T_{\mathrm{n}}$ for the B1 scenario, $+1.0(+2.4)^{\circ} \mathrm{C}$ for the A1B scenario, and $+1.7(+2.6)^{\circ} \mathrm{C}$ for the A2 scenario. This shows that future HWs seem to be associated with a worsening of thermal conditions at night, all the more significant since the emission scenario is pessimistic. However, these findings among emission scenarios must be considered with caution because the differences in temperature (both for $T_{\mathrm{n}}$ and $T_{\mathrm{x}}$ ) noted between heat waves extracted from ARPEGE projections for scenarios $\mathrm{B} 1, \mathrm{~A} 1 \mathrm{~B}$, and $\mathrm{A} 2$ are of the same order of magnitude or even lower than the standard deviations calculated from the temperatures of heat waves extracted from the ENSEMBLES database (performed with A1B emission scenario).

Finally, for both ENSEMBLES and Météo-France historical runs, $100 \%$ of HWs take place in July/ August. But, at the end of the century, the HW season extends from June to September - with some days even in May-because HWs become longer (the days adjacent to HW peaks extend beyond July and August), or because isolated events occur in June and September.

\subsection{Relation between mean warming and occurrence of heat waves}

For all the ENSEMBLES and ARPEGE climate projections, the mean warming in minimum $\left(\Delta T_{\mathrm{n}}\right)$ and maximum $\left(\Delta T_{\mathrm{x}}\right)$ daily temperatures (for the 6 mo pe- riod from May to October) was computed between 1960-1989 and 2020-2049 and between 1960-1989 and 2070-2099. These mean trends were compared to the increase in both the number of heat waves ( $\Delta \mathrm{HWs}$ ) and the number of heat wave days ( $\Delta \mathrm{HW}$ days) over the same time periods (Fig. 7). Simple linear relationships are observed between these trends, whether between $\Delta T_{\mathrm{n}}$ and $\Delta \mathrm{HWs} / \Delta \mathrm{HW}$ days or between $\Delta T_{\mathrm{x}}$ and $\Delta$ HWs/ $\Delta$ HW days, with high correlation coefficients. R-squared reaches 0.89 and 0.82 for $\Delta T_{\mathrm{x}}$ compared to $\Delta$ HWs and $\Delta$ HW days, respectively, while it is slightly lower but significant for $\Delta T_{\mathrm{n}}(0.71$ and 0.58$)$. It therefore seems possible to determine the changing occurrences of heat waves from average seasonal trends. There is a slight dispersion between models, especially for $\Delta T_{\mathrm{n}}$. Some models, such as HIRHAM and REMO (both driven by ECHAM), are systematically below the linear regression line, whereas ARPEGE, ALADIN (driven by CNRM-CM3), and HIRHAM (when also driven by CNRM-CM3) are above. These differences are directly related to a more or less marked intra-seasonal variability. Finally, it is also interesting to note that for both $\Delta \mathrm{HWs}$ and $\Delta \mathrm{HW}$ days, the slope is a little higher for $\Delta T_{\mathrm{n}}$ than for $\Delta T_{\mathrm{x}}$, which means that the heat wave occurrences are more influenced by the mean increase in minimum daily temperature than in maximum daily temperature.

\section{CONCLUSIONS}

We analysed the evolution over time of the occurrence frequency of heat waves in the Paris region in a changing future climate (1960-1989, 2020-2049, 2070-2099). Firstly, a method for extracting heat waves from observed or simulated time series of daily maximum and minimum temperatures was pro- 


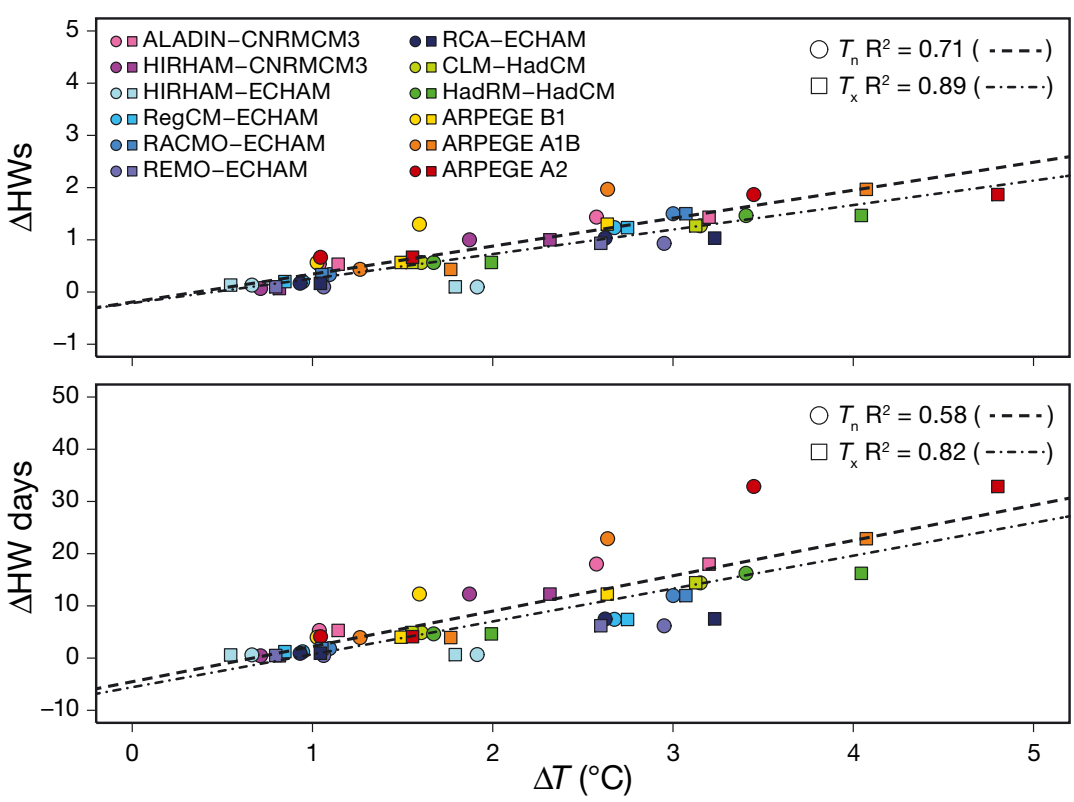

Fig. 7. Comparison between the mean warming trends in $T_{\mathrm{n}}$ and $T_{\mathrm{x}}$, and the increase in number of heat waves (HWs, top) and in number of heat wave days (bottom). These trends were computed between 1960-1989 and 2020-2049 and between 1960-1989 and 2070-2099 for all scenarios

HWs than RCMs driven by ECHAM. The choice of RCM does not seem to be negligible even though a larger ensemble must be used to confirm the relative role of the GCM choice versus RCM choice. This will be one of the major advantages of the CORDEX program, which is just starting and for which a large GCM-RCM matrix is currently being produced by the modeling groups (Giorgi et al. 2009, Jacob et al. 2013). The comparison of the HWs simulated with the 3 different emission scenarios highlights the major impact of the scenario on the number of HW days (and the duration of HWs) at the end of the 21st century, whereas it is not significant for 2020-2049.

This work assesses the range of variation of HWs that could affect the city of Paris in the future. The results obtained for the end of the 21st century highlight the need to implement

posed. It was evaluated over 1951-2009 using observations from 2 meteorological stations of the MétéoFrance operational network. Heat waves that affected the Paris region in the past were correctly identified in terms of both dates and durations. Note that 8 heat waves were extracted during this period (i.e. a mean frequency of 1 in $>7 \mathrm{yr}$ ).

The method was next applied to a large sample of climate projections, including $1 \mathrm{RCM}$ following 3 emission scenarios (A2, A1B, B1) and 9 combinations of RCMs driven by different GCMs following the A1B emission scenario only (from the ENSEMBLES European project). For all of them, the time series of minimum and maximum temperature were corrected by the quantile-quantile matching correction method in an earlier step. The historical runs generated 1-5 heat waves, depending on the model, with a median value of 3 events (i.e. a mean frequency of 1 in $10 \mathrm{yr}$ ). All models from the ENSEMBLES database simulated a systematic increase in the frequency of occurrence of HWs with time: 1 heat wave every 2 yr on average over 2020-2049 and at least 1 heat wave per year and up to 2 heat waves per year on average over 20702099; they also became much longer, with mean durations varying between 6 and 12 d in 2070-2099 and exceptional durations reaching 5-9 wk. The comparison of this set of climate projections seems to indicate a significant influence of the forcing GCM. RCMs driven by CNRM-CM3 and HadCM tended to simulate more effective mitigation and adaptation strategies in order to reduce the vulnerability of cities and urban populations to such extreme events. This is all the more pertinent given that the cities are already affected today by the urban heat island, which is characterized by higher temperatures in urban environments than in the surrounding countryside, particularly at night. It is believed that this effect is superimposed on global warming and exacerbates HW situations. To illustrate this issue, HWs were extracted from the time series recorded at Montsouris Park in central Paris using the methodology presented here for 1960-1989. The results are included in Fig. 4 (referred to as OBS[urban]) and in Table 4 (referred to as urban). A strong increase in the number of HWs due to the urban heat island effect is shown (Table 4): 6 events were identified compared to just 1 from the reference historical time series. The statistical analysis over 1951-2000 also indicates that $T I_{\mathrm{m}}$ is $1^{\circ} \mathrm{C}$ warmer for the urban time series than for the rural reference (Fig. 4). Within the framework of the French research project VURCA (Vulnérabilité URbaine aux épisodes Caniculaires et stratégies d'Adaptation: the French acronym for Vulnerability of cities to future heat waves and adaptation strategies), for which this study is a part, numerical simulations will be performed in order to study the evolution of the Parisian urban climate and, particularly, the urban heat island, under conditions of future heat waves. 
Acknowledgements. This study benefited from funding by the French Agency for Research (ANR) through the VURCA project (ANR-08-VULN-013). The authors are grateful to Michel Déqué for running the variable-resolution ARPEGE model and for his advice on climate model analysis, and to Brigitte Dubuisson for her recommendations on long-term observation time series. The climate model outputs came from the ENSEMBLES project, funded by the European Commission's 6th Framework Program.

\section{LITERATURE CITED}

Beaulant AL, Joly B, Nuissier O, Somot S and others (2011) Statistico-dynamical downscaling for Mediterranean heavy precipitation. QJR Meteorol Soc 137:736-748

Beniston M, Stephenson D, Christensen O, Ferro C and others (2007) Future extreme events in European climate: an exploration of regional climate model projections. Clim Change 81(Suppl 1):71-95

Boé J, Terray L, Habets F, Martin E (2006) A simple statistical-dynamical downscaling scheme based on weather types and conditional resampling. J Geophys Res 111(D23106), doi:10.1029/2005JD006889

Böhm U, Kücken M, Ahrens W, Block A and others (2006) CLM-the climate version of LM: brief description and long-term applications. COSMO Newsletter 6:225-235

> Casati B, Yagouti A, Chaumont D (2013) Regional climate projections of extreme heat events in nine pilot Canadian communities for public health planning. J Appl Meteorol Climatol 52:2669-2698

$>$ Chauvin F, Denvil S (2007) Changes in severe indices as simulated by two French coupled global climate models. Global Planet Change 57:96-117

Christensen J, Christensen O, Lopez P, van Meijgaard E, Botzet M (1996) The HIRHAM4 regional atmospheric climate model. Report 96-4, Scientific report DMI, Copenhagen

Christensen JH, Boberg F, Christensen OB, Lucas-Picher P (2008) On the need for bias correction of regional climate change projections of temperature and precipitation. Geophys Res Lett 35:L20709, doi:10.1029/2008GL035694

Colin J, Déqué M, Radu R, Somot S (2010) Sensitivity study of heavy precipitation in Limited Area Model climate simulations: influence of the size of the domain and the use of the spectral nudging technique. Tellus, Ser A, Dyn Meterol Oceanogr 62:591-604

> Collins M, Booth B, Harris G, Murphy J, Sexton D, Webb M (2006) Towards quantifying uncertainty in transient climate change. Clim Dyn 27:127-147

> Cueto R, Tejeda-Martínez A, Jáuregui-Ostos E (2010) Heat waves and heat days in an arid city in the northwest of Mexico: current trends and in climate change scenarios. Int J Biometeorol 54:335-345

Déqué M (2005) Impact des changements anthropiques sur la fréquence des phénomènes extrêmes de vent, de température et de précipitations. IMFREX Final Report. http: //imfrex.sedoo.fr/web/documents/downloads/rapport_ final_imfrex.pdf (accessed 1 September 2014)

Déqué M (2007) Frequency of precipitation and temperature extremes over France in an anthropogenic scenario: model results and statistical correction according to observed values. Glob Planet Change 57:16-26

> Déqué M, Rowell DP, Lüthi D, Giorgi F and others (2007) An intercomparison of regional climate simulations for
Europa: assessing uncertainties in model projections. Clim Change 81:53-70

> Déqué M, Somot S, Sanchez-Gomez E, Goodess CM, Jacob D, Lenderink G, Christensen OB (2012) The spread amongst ENSEMBLES regional scenarios: regional climate models, driving general circulation models and interannual variability. Clim Dyn 38:951-964

> Driouech F, Déqué M, Sánchez-Gómez E (2010) Weather regimes-Moroccan precipitation link a regional climate change simulation. Glob Planet Change 72:1-10

Dubuisson B, Moisselin JM (2006) Evolution des extrêmes climatiques en France à partir des séries observées. Houille Blanche 6:42-47

Ducharne A, Sauquet E, Habets F, Déqué M and others (2011) Evolution potentielle du régime des crues de la Seine sous changement climatique. Houille Blanche 1:51-57

Durand Y, Brun E, Merindol L, Guyomarc'h G, Lesaffre B, Martin E (1993) A meteorological estimation of relevant parameters for snow models. Ann Glaciol 18:65-71

Durand Y, Giraud G, Brun E, Merindol L, Martin E (1999) A computer-based system simulating snowpack structure as a tool for regional avalanche forecasting. J Glaciol 45: 469-484

- Easterling D, Horton B, Jones $\mathrm{P}$, Peterson $\mathrm{T}$ and others (1997) Maximum and minimum temperature trends for the globe. Science 277:364-367

Evin C, d'Aubert F (2004) Rapport fait au nom de la commission d'enquête sur les conséquences sanitaires et sociales de la canicule. N1455, Tome 1, report recorded at the Presidency of the French National Assembly on 25 February 2004

Fischer E, Schär C (2010) Consistent geographical patterns of changes in high-impact European heat waves. Nat Geosci 3:398-401

Fischer EM, Seneviratne SI, Lüthi D, Schär C (2007) Contribution of land-atmosphere coupling to recent European summer heat waves. Geophys Res Lett 34:L06707, doi: 10.1029/2006GL029068

Gibelin A, Déqué M (2003) Anthropogenic climate change over the Mediterranean region simulated by a global variable resolution model. Clim Dyn 20:327-339

> Giorgi F (2006) Climate change hot-spots. Geophys Res Lett 33:L08707, doi:10.1029/2006GL025734

Giorgi F, Mearns L (1999) Introduction to special section: regional climate modeling revisited. J Geophys Res D 104:6335-6352

Giorgi F, Jones C, Asrar GR (2009) Addressing climate information needs at the regional level. The CORDEX framework. WMO Bull 58:175-183

Goodess C (2003) STAtistical and Regional dynamical Downscaling of EXtremes for European regions: STARDEX. www.cru.uea.ac.uk/projects/stardex/reports/STARDEX_ FINAL_REPORT.pdf (accessed 1 September 2014)

Houghton J, Ding Y, Griggs D, Noguer M and others (2001) Climate change 2001: the scientific basis. Contribution of Working Group I to the 3rd assessment report of the Intergovernmental Panel on Climate Change. Cambridge University Press, Cambridge

Huth R, Kyselý J, Pokorná L (2000) A GCM simulation of heatwaves, dry spells and their relationship to circulation. Clim Change 46:29-60

IPCC (Intergovernmental Panel on Climate Change) (2007) Climate change 2007: the physical science basis. Contribution of Working Group I to the 4th assessment report of the Intergovernmental Panel on Climate Change. Cam- 
bridge University Press, Cambridge

Jacob D (2001) A note to the simulation of the annual and inter-annual variability of the water budget over the Baltic Sea drainage basin. Meteorol Atmos Phys 77:61-73

> Jacob D, Andrae U, Elgered G, Fortelius C and others (2001) A comprehensive model intercomparison study investigating the water budget during the BALTEX-PIDCAP period. Meteorol Atmos Phys 77:19-43

Jacob D, Petersen J, Eggert B, Alias A and others (2013) EURO-CORDEX: new high-resolution climate change projections for European impact research. Reg Environ Change 14:563-578

Kjellström E, Bärring L, Gollvik S, Hansson U and others (2005) A 140-year simulation of European climate with the new version of the Rossby Centre regional atmospheric climate model (RCA3). Rep Meteorol Climatol 108, SMHI, Norrköping

Kuglitsch FG, Toreti A, Xoplaki E, Della-Marta PM, Zerefos CS, Tükes M, Luterbacher J (2010) Heat wave changes in the eastern Mediterranean since 1960. Geophys Res Lett 37:L04802, doi:10.1029/2009GL041841

> Lemonsu A, Kounkou-Arnaud R, Desplat J, Salagnac JL, Masson V (2013) Evolution of the Parisian urban climate under a global changing climate. Clim Change 116: 679-692

Lenderink G, van den Hurk B, van Meijgaard E, Ulden A, Cuijpers J (2003) Simulation of present-day climate in RACMO2: first results and model developments. KNMI Technical Report 252, KNMI, De Bilt

Maillard C (2010) Alerte canicule. Météo 10:7-9

- Maraun D (2012) Nonstationarities of regional climate model biases in European seasonal mean temperature and precipitation sums. Geophys Res Lett 39:L06706, doi: 10.1029/2012GL051210

Martin E, Etchevers P (2006) Impact of climatic changes on snow cover and snow hydrology in the French Alps. Adv Global Change Res 23:235-242

> Meehl GA, Tebaldi C (2004) More intense, more frequent, and longer lasting heat waves in the 21st century. Science 305:994-997

Moisselin J, Schneider M, Canellas C, Mestre O (2002) Les changements climatiques en France au XXe siècle: étude des longues séries homogénéisées de données de température et de précipitations. Meteorologie 38:45-56

Mueller B, Seneviratne SI (2012) Hot days induced by precipitation deficits at the global scale. Proc Natl Acad Sci USA 109:12398-12403

Perkins SE, Alexander LV (2013) On the measurement of heat waves. J Clim 26:4500-4517

Perkins SE, Alexander LV, Nairn JR (2012) Increasing fre- quency, intensity and duration of observed global heatwaves and warm spells. Geophys Res Lett 39:L20714, doi:10.1029/2012GL053361

Najac J, Vidal JP, Martin E, Franchistéguy L, Soubeyroux JM (2010) Changes in drought characteristics in France during the 21st century. Geophys Res Abstr 12: EGU2010-8975 (abstract)

> Planton S, Déqué M, Chauvin F, Terray L (2008) Expected impacts of climate change on extreme climate events. C R Geosci 340:564-574

Robinson P (2001) On the definition of a heat wave. J Appl Meteorol 40:762-775

Rosenzweig C, Solecki W (2001) Climate change and a global city - learning from New York. Environment 43:8-18

Rousseau D (2004) Analyse fine des surmortalités pendant la canicule 2003. L'événement météorologique de la nuit du 11 au 12 août 2003 en Ile-de-France. Meteorologie 51: 16-22

Rousselot M, Durand Y, Giraud G, Mérindol L, DombrowskiEtchevers I, Déqué M, Castebrunet H (2012) Statistical adaptation of ALADIN RCM outputs over the French Alps - application to future climate and snow cover. Cryosphere 6:785-805

Schär C, Vidale P, Lüthi D, Frei C, Häberli C, Liniger M, Appenzeller C (2004) The role of increasing temperature variability in European summer heat waves. Nature 427: 332-336

Smoyer-Tomic K, Kuhn R, Hudson A (2003) Heat wave hazards: an overview of heat wave impacts in Canada. Nat Hazards 28:465-486

Teutschbein C, Seibert J (2012) Bias correction of regional climate model simulations for hydrological climatechange impact studies: review and evaluation of different methods. J Hydrol (Amst) 456-457:12-29

van der Linden P, Mitchell J (2009) ENSEMBLES: climate change and its impacts: summary of research and results from the ENSEMBLES project. Met Office Hadley Centre, Exeter

Vautard R, Yiou P, D'Andrea F, de Noblet N and others (2007) Summertime European heat and drought waves induced by wintertime Mediterranean rainfall deficit. Geophys Res Lett 34:L07711, doi:10.1029/2006GL028001

Vautard R, Noël T, Li L, Vrac M and others (2012) Climate variability and trends in downscaled high-resolution simulations and projections over Metropolitan France. Clim Dyn 41:1419-1437

Wilby R, Wigley T, Conway D, Jones P, Hewitson B, Main J, Wilks D (1998) Statistical downscaling of general circulation model output: a comparison of methods. Water Resour Res 34:2995-3008 
Appendix. Application of the method used to other French regions

The method of extraction of heat waves implemented in the main part of the study for the Paris region was also applied to other locations in France in order to evaluate its robustness. Six time series of observed daily minimum and maximum temperatures, available from 1975 for the regions of Bordeaux, Lille, Lyon, Nantes, Strasbourg, and Toulouse (see locations in Fig. A1), were selected. For each station, heat waves were extracted according to the same techniques (see Section 2.2), but by using the different temperature thresholds prescribed by the Plan National Canicule, depending on the administrative counties.

The results are presented in Table A1 for the most significant heat waves, which are mentioned in the MétéoFrance archives $(1976,1983,2003$, and 2006). As shown in Fig. 2, these 4 events arose as a result of different largescale meteorological conditions, and did not affect the whole country in the same way in each case: the 1976 heat wave mainly hit the northern half of France, whereas the 1983 heat wave was especially marked in the southeast of France and, to a lesser extent, in the eastern part of the country. The 2003 and 2006 heat waves both hit the whole country, although the 2006 heat wave started earlier in the southern half of France before extending to the north.

These differences in impacts on a regional scale are correctly captured by the method of heat wave extraction applied to 7 regions in France. The 1976 heat wave is extracted only from the time series recorded at the stations located in the northern part of the country, i.e. Lille, Nantes, Paris, and Strasbourg. Note that the dates and durations of events obtained for each region are similar to each other and with what is recorded in the Météo-

France archives (Table A1). Only the stations close to Lyon and Strasbourg (east and northeast of France, respectively) indicate the occurrence of a heat wave in July 1983, which is consistent with the meteorological situation (see Fig. 2). However, the recorded events are shorter than the heat wave archived (23 d) because this event principally affected the southeast of France, and then extended to the northeast, reaching the regions of Lyon (15 d) and Strasbourg (6 d). Finally, the 2003 and 2006 heat waves are both identified at all the stations, whatever the region of France. The 2003 event is especially well defined, with very similar durations from one region to another: the heat wave starts between 1 and 3 August, with durations of 10-13 d, whereas the archived event is 2-14 August. For 2006, the results are more variable. They indicate that the heat wave ended 1 wk earlier in the regions of Bordeaux and Lille, whereas it lasted until 27 July in the other regions, in accordance with the archived data (Table A1).

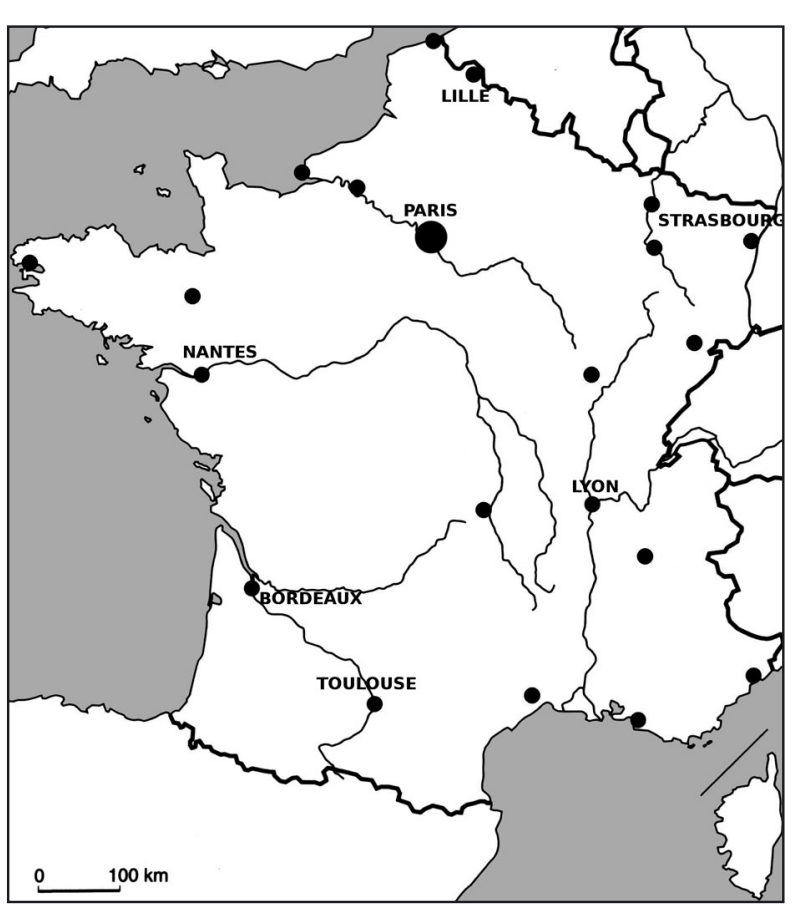

Fig. A1. Geographic locations of the French regions for which the method of extraction of heat waves has been applied and evaluated

Table A1. Extraction of the most extreme heat waves (HW) events in different regions of France, extracted from the comparison with past HW events over France compiled in the Météo-France archives. Period of the HW is given and its duration (in parentheses)

\begin{tabular}{|c|c|c|c|c|}
\hline & \multicolumn{4}{|c|}{ Past HWs over France } \\
\hline & 1976 & 1983 & 2003 & 2006 \\
\hline $\begin{array}{l}\text { France (cf. Météo- } \\
\text { France archives) }\end{array}$ & $\begin{array}{l}23 \mathrm{Jun}-7 \mathrm{Jul} \\
(15 \mathrm{~d})\end{array}$ & $\begin{array}{l}8-31 \mathrm{Jul} \\
(23 \mathrm{~d})\end{array}$ & $\begin{array}{l}\text { 2-14 Aug } \\
(13 \mathrm{~d})\end{array}$ & $\begin{array}{c}\text { 10-28 Jul } \\
(19 \mathrm{~d})\end{array}$ \\
\hline Bordeaux & - & - & $\begin{array}{l}\text { 1-11 Aug } \\
(11 \mathrm{~d})\end{array}$ & $\begin{array}{c}14-20 \mathrm{Jul} \\
(7 \mathrm{~d})\end{array}$ \\
\hline Lille & $\begin{array}{l}\text { 22 Jun-6 Jul } \\
(15 \mathrm{~d})\end{array}$ & - & $\begin{array}{l}\text { 3-12 Aug } \\
(10 \mathrm{~d})\end{array}$ & $\begin{array}{c}16-20 \mathrm{Jul} \\
(5 \mathrm{~d})\end{array}$ \\
\hline Lyon & - & $\begin{array}{l}16-30 \mathrm{Jul} \\
(15 \mathrm{~d})\end{array}$ & $\begin{array}{l}\text { 1-13 Aug } \\
(13 \mathrm{~d})\end{array}$ & $\begin{array}{l}\text { 19-27 Jul } \\
(9 \mathrm{~d})\end{array}$ \\
\hline Nantes & $\begin{array}{l}21 \text { Jun-3 Jul } \\
(13 \mathrm{~d})\end{array}$ & - & $\begin{array}{l}\text { 2-13 Aug } \\
(12 \mathrm{~d})\end{array}$ & $\begin{array}{l}\text { 14-26 Jul } \\
(13 \mathrm{~d})\end{array}$ \\
\hline Paris & $\begin{array}{l}23 \text { Jun-6 Jul } \\
(14 \mathrm{~d})\end{array}$ & - & $\begin{array}{l}2-13 \text { Aug } \\
(12 \mathrm{~d})\end{array}$ & $\begin{array}{l}\text { 15-26 Jul } \\
(12 \mathrm{~d})\end{array}$ \\
\hline Strasbourg & $\begin{array}{l}25 \text { Jun-5 Jul } \\
\text { (11 d) }\end{array}$ & $\begin{array}{c}25-30 \mathrm{Jul} \\
(6 \mathrm{~d})\end{array}$ & $\begin{array}{l}\text { 1-13 Aug } \\
(13 \mathrm{~d})\end{array}$ & $\begin{array}{l}17-27 \mathrm{Jul} \\
(11 \mathrm{~d})\end{array}$ \\
\hline Toulouse & - & - & $\begin{array}{c}1-13 \text { Aug } \\
(13 \mathrm{~d})\end{array}$ & $\begin{array}{l}12-25 \mathrm{Jul} \\
(14 \mathrm{~d})\end{array}$ \\
\hline
\end{tabular}

